\title{
Warisan Budaya Orang Selayar (Menggugat Eksistensi Atas Nama Identitas)
}

\author{
A H M A D I N \\ Dosen Jurusan Sejarah UNM
}

\begin{abstract}
Abstrak
Masyarakat dan kebudayaannya, merupakan dua sisi dari satu kenyataan sosial kehidupan manusia yang tidak dapat dipisahkan secara dikotomis. Demikian pula tradisi sebagai salah satu wujud kebudayaan, merupakan penciri suatu masyarakat atau komunitas sehingga hal-hal yang berhubungan dengan satu kebiasaan selalu dihubungkan dengan etnis tertentu. Meskipun demikian, pengaruh modernisasi dalam berbagai aspek kehidupan dengan ragam suguhan sebagai tuntutan zaman, secara gradual memperkeruh otentitas budaya lokal hingga mengikisnya secara perlahan. Karena itu, jika tidak ada upaya ke arah pengenalan atas warisan budaya sendiri, maka dapat dipastikan generasi masa depan akan kehilangaan identitas dan kebanggaan kulturalnya. Pada saat yang sama, sistem sosial sebagai bagian integral dari kebudayaan akan kehilangan roh atau berkembang tanpa pijakan yang jelas.
\end{abstract}

\section{Kata Kunci : Warisan Budaya}

\section{Pendahuluan}

Berbicara mengenai budaya terutama dalam tataran pengertian, maka alur pemikiran kita setidaknya masih akan bermain diantara kebingungan akibat banyaknya defenisi yang ada. Bahkan belum lagi terjawab keraguan akan sulitnya menentukan dari mana seharusnya memulai penyadapan makna kata budaya tersebut, keinginan kuat untuk mendefinisikannya masih terpengaruh oleh belum adanya kata sepakat di kalangan para antropolog mengenai defenisi final dari budaya tersebut. Konsekuensi logis dari kenyataan ini, menyebabkan setiap orang masingmasing menggunakan defenisi tentang budaya yang diyakininya untuk dijadikan landasan teori. Meskipun demikian, bukan berarti bahwa defenisi lainnya lalu dinggap tidak berfungsi akan tetapi penggunaannya lebih disesuaikan dengan konteks kajian.

Salah satu defenisi budaya (kebudayaan) yang sering dianggap tertua usianya, sekaligus menjadi landasan bagi perkembangan konsep kebudayaan sesudahnya yakni formulasi yang dikemukakan oleh E.B. Tylor, penulis buku ternama "Primitive Culture" ini, pernah mengemukakan bahwa kebudayaan atau peradaban merupakan suatu keseluruhan yang kompleks mencakup pengetahuan, kepercayaan, kesenian, moral, hukum, adat-istiadat, dan lainlain kemampuan-kemampuan serta kebiasaan-kebiasaan yang didapatkan oleh manusia sebagai anggota masyarakat (Tylor, 1924: 1).

Mengacu pada defenisi kebudayaan tersebut, maka dapat dipahami bahwa tidak ada masyarakat yang tidak berbudaya, sebaliknya tidak ada kebudayaan tanpa masyarakat sebagai wadah dan pendukung. Atas dasar pemikiran seperti itulah sehingga dapat dipahami bahwa segala yang ada dalam suatu masyarakat, pada prinsipnya sangat ditentukan oleh tradisi dan 
kebudayaan yang dimiliki oleh pendukungnya. Hasil interaksi antar manusia baik antar individu dengan individu, individu dengan kelompok, dan kelompok dengan kelompok pada gilirannya melahirkan wujud kebudayaan seperti benda, kompleks ide atau gagasan, dan tingkah laku yang terpola. Karena itu, dikenal unsur kebudayaan meliputi peralatan dan sistem perlengkapan hidup manusia, mata pencaharian dan sistem ekonomi, sistem kemasyarakatan, bahasa, kesenian, sistem pengetahuan, dan religi (Kroeber ed, 1953: 507-523).

Sebagaimana tulisan ini yang akan membahas tentang warisan budaya orang Selayar, maka sudah barang tentu harus menelusuri setiap relung-relung kehidupan suku ini dari berbagai aspek. Hal ini dipahami bahwa secara sosial untuk memahami suatu masyarakat harus dilihat sebagai suatu sistem, yang memiliki keterkaitan secara korelasional antara satu dengan yang lain sebagai suatu kompleksitas kehidupan. Demikian pentingnya upaya pemahaman secara komprehensif mengenai identitas orang Selayar, maka penelusuran aspek sosio-kultural terhadap etnis ini sangat penting artinya. Dalam pengertian lain bahwa aspek mentalitas yang terpola dari sebuah construct society sebagai aspek dinamika dari kelangsungan hidup bermasyarakat, akan sangat menentukan berbagai kecenderungan setiap orang baik secara individu (pribadi) maupun kolektif dalam menentukan pilihan-pilihan hidup.

Kondisi sosial-budaya masyarakat di kabupaten Selayar dari masa ke masa, pada prinsipnya merupakan bagian integral yang tak terpisahkan secara parsial sebagai suatu dinamika. Kondisi budaya tersebut yakni stratifikasi sosial, sistem kekerabatan, serta agama dan kepercayaan yang berlaku pada masyarakat yang bersangkutan.

\section{Stratifikasi Sosial}

Stratifikasi sosial suatu masyarakat pada hakekatnya dipahami sebagai latar belakang pandangan hidup, watak atau sifat-sifat mendasar, bahkan merupakan warna dan corak dari hubungan-hubungannya. Istilah ini berasal dari kata stratum sebagai jamak dari strata yang mengandung arti lapisan yakni pembedaan penduduk atau masyarakat berdasarkan kelas secara bertingkat (hierarkis). Dalam tataran implementasinya, tampil dalam tiga wujud yakni kelas atas (upper class), menengah (midle class) dan bawah (lower class). Dasar dan inti adanya lapisan masyarakat yakni karena tidak adanya keseimbangan dalam distribusi mengenai hak dan kewajiban, kewajiban dan tanggung jawab nilai-nilai sosial dan pengaruhnya diantara anggotaanggota masyarakat (Sorokin, 1959: 11; Soekanto, 2001: 251-268).

Stratifikasi sosial masyarakat Selayar pada umumnya, sama dengan sistem pelapisan sosial pada masyarakat Bugis-Makassar. Mengenai awal keberadaannya sangat sulit ditelusuri, namun jauh sebelum kaum kolonial menginjakkan kakinya di Sulawesi Selatan, tipe stratifikasi ini telah lama berlaku. Pelapisan sosial tersebut, yakni berdasarkan keturunan (ascribed status). Dalam perspektif Friedericy, pelapisan sosial masyarakat Bugis-Makassar terdiri atas 3 lapisan yakni Anak Karaeng, Tomaradeka, dan Ata. (Mattulada, 1975: 25).

Sejak zaman dahulu di kalangan masyarakat Selayar sendiri pada umumnya, juga mengenal stratifikasi sosial berdasarkan keturunan seperti Daeng atau Opu (keluarga karaeng), panrita (cerdik pandai/cendikiawan tradisional), ata atau pasompo-sompo poke (keturunan pengawal Opu atau Karaeng yang bersenjatakan poke/tombak). Stratifikasi sosial paling bawah (lower class) dinamakan tau samara (orang kebanyakan) yang hidup di luar struktur pemerintahan dan biasanya sebagian dari mereka menjadi pengabdi pada mereka yang lebih tinggi strata sosialnya. Khusus mereka yang bertugas mengawal penguasa (raja) dikenal dengan 
istilah pallapi barambang (pelapis dada, makna ettimologi dalam bahasa Indonesia). Selain itu, untuk kategori tau samara, juga dikenal paalle ruku' (tukang pengumpul rumput untuk makanan kuda milik tuannya).

Kategori strata sosial pertama dalam kehidupan sehari-hari senantiasa dihormati, seperti dalam acara pesta perkawinan ia ditempatkan (duduk) pada posisi sebelah (bagian) barat dari rumah pesta (attolong lau'). Kategori kedua dari stratifikasi sosial ini dalam masyarakat juga diperlakukan istimewa mungkin karena pengetahuan yang dimilikinya tentang berbagai hal baik yang menyangkut norma ( $a d a^{\prime}$ ), pengetahuan tentang kesaktian (pangissengang), maupun ilmu agama atau tarekat (setelah masuknya ajaran Islam). Meskipun tingkat pengetahuan para panrita itu bervariasi, namun tidak lagi dikenal stratifikasi sebagai pembeda antara satu dengan yang lain.

Memperhatikan stratifikasi sosial untuk kategori ascribed status ini, secara fungsional sama dengan stratifikasi masyarakat Bugis-Makassar dan etnis lainnya di Sulawesi Selatan. Jenjang tersebut antara lain kaum bangsawan (keluarga/keturunan raja), orang yang merdeka (tanpa ikatan) dan rakyat jelata (menyerupai budak). Bahkan satu profesi sosial tradisional lagi semisal sanro (petugas kesehatan atau ahli nujum) statusnya sama dengan panrita (to maradeka) dan umum berlaku di tanah Celebes ini. Pada komunitas adat Karampuang di Kabupaten Sinjai, profesi sanro mutlak berasal dari kaum perempuan. Di Selayar justru terbagi atas dua yakni sanro mana (dukun bersalin) yang mutlak adalah perempuan dan sanro kampong atau tau ngilei, umumnya laki-laki namun tidak menutup kemungkinan juga adalah perempuan. Bagi mereka yang masih fanatik terhadap keampuhan pattahara (mantra)para sanrom hingga sekarang, justru enggan menggunakan jasa dokter dalam berobat jika sakit.

Meskipun demikian, dapat diketahui bahwa tampaknya predikat bangsawan (tradisional) bagi orang tertentu saat sekarang ini tak ubahnya hanya sebagai simbol belaka. Stratifikasi sosial lebih diukur berdasarkan indikator ekonomi seperti pemilik modal dan pemilik berbagai fasilitas hidup mewah yang menempati posisi penting dalam masyarakat. Melengkapi parameter status sosial yakni materi tersebut, jenjang pendidikan sebagai achieved status yang dimiliki oleh seseorang, pun menjadi ukuran mengenai status seseorang dalam masyarakatnya.

\section{Sistem Kekerabatan}

Sistem kekerabatan di kalangan masyarakat Bugis-Makassar di Sulawesi Selatan, hingga hari ini kelihatannya masih tetap dipertahankan dan dijunjung tinggi. Sistem tersebut dikenal dalam berbagai istilah seperti passibijaeng (Makassar), ada' assiwijangen (Bugis) dan passibijaan (Selayar). Sistem kekerabatan yang berlaku di Selayar, adalah sistem bilateral (parental). Kerena itu, hubungan kekeluargaan seseorang dapat ditelusuri melalui dua jalur, yakni melalui hubungan kekeluargaan dari garis keturunan ayah maupun dari Ibu (Paeni dan Kathryn Robinson, ed., 1985: 10).

Kelompok kekerabatan tersebut juga terbentuk melalui dua pola, yakni pola kelahiran dan perkawinan. Terminologi kerabat dalam bahasa Selayar disebut bija, yang dapat digolongkan menjadi dua bagian yakni bija pammanakang dan bija passianakang. Kategori bija pertama adalah kelompok kekerabatan yang terbentuk melalui jalur kelahiran dan kategori bija kedua terbentuk melalui jalur ikatan perkawinan. Sementera itu, kekerabatan dalam unit sosial terkecil dinamakan bija pammanakang sibatu sapo, yakni mencakup keluarga luar (extended family) dan segenap keluarga yang tinggal bersama-sama dalam satu rumah tangga atau nuclear family (Ahmadin, 2001: 57). 
Makna tinggal bersama dalam konsep ini yakni setiap individu dalam satu rumah tangga merupakan satu kesatuan (sistem sosial), baik ditinjau dari aspek ekonomi, budaya maupun agama. Bahkan lebih dari itu sebuah mekanisme integrasi dan pemersatu juga tampak dalam wujud lain dimana masyarakat Selayar juga mengenal istilah siri' dalam interaksi sosial sebagaimana yang berlaku umum pada berbagai masyarakat di setiap daerah Sulawesi Selatan.

Makna istilah ini telah banyak ditafsirkan oleh para peneliti, sebut saja B.F. Matthes umpamanya mengartikannya dengan malu (beachaamd), kemudian takut (achroomvalling), malu-malu (verlegent), kehormatan (eergovoel), aib (schande), dan dengki (wangusnt) (Mattulada, 1975: 29). Dalam konteks yang lebih luas siri' juga berarti manisfestasi budaya dalam hal martabat dan harga diri manusia dalam kehidupan kemasyarakatan. Demikian penting dan berharganya siri' tersebut sehingga eksistensi sebagai manusia dalam kehidupannya sangat ditentukan oleh siri' ini dan bagi mereka yang tidak memilikinya dianggap tidak lebih hanya sebagai binatang. Sebagaimana pernyataan: "only with siri' are we called human, if we have not siri we are not human. That's called; human in form only and the person who is without siri' is not different from an animal" (Erington, 1979: 146).

Karena itu, merupakan fenomena wajar jika setiap persoalan merupakan tanggung jawab bersama dan solusi alternatif pemecahannya juga selalu berusaha ditemukan secara bersamasama. Pemegang otoritas tradisional tertinggi dalam penyelesaian persoalan yang berhubungan dengan kehidupan sehari-hari adalah tau toana kampung (orang yang dituakan dan dihormati dalam masyarakat). Kecenderungan ini merupakan manifestasi dari prinsip siri'ta ngase (harga diri secara kolektif). Modus penyelesaian berbagai masalah yang berhubungan dengan kehidupan bermasyarakat tersebut, sejak dahulu dilakukan melalui pertemuan yang disebut a'rappung (kumpul dan duduk bersama). Orang Bugis sebagai salah satu etnis di tanah Celebes ini menamakan istilah sejenis dengan tudang sipulung. Interaksi sosial semacam ini dalam paradigma ilmu sosial diistilahkan sebagai solidaritas sosial mekanik atau collective action (Durkheim, 1984: 11).

Tipe kehidupan masyarakat semacam ini dihubungkan dengan social relationship yakni ikatan ideologi atau kepercayaan terhadap pesan leluhur. Pengingkaran terhadap leluhur disebut kapalli, sehingga teguran pada seseorang yang melanggar berbunyi "akoppakonjo kapalli" (jangan begitu pemali). Karena itu, adanya interaksi sosial yang berlangsung karena ikatan kultural, pada dasarnya disebabkan oleh munculnya sentiment community yang unsur-unsurnya adalah sebagai berikut: (1) Seperasaan, yakni karena seseorang berusaha untuk mengidentifikasi dirinya dengan sebanyak mungkin orang dalam kelompok tersebut, sehingga kesemuanya dapat menyebutkan dirinya sebagai kelompok kami, perasaan kami dan sebagainya. Sepenanggungan, yakni setiap individu sadar akan peranannya dalam kelompok dan keadaan masyarakat sendiri sangat memungkinkan peranannya dalam kelompok dijalankan. (3) Saling butuh, yakni individu yang tergabung dalam masyarakat setempat merasakan dirinya tergantung pada community-nya yang meliputi kebutuhan fisik maupun psikologis (Soekanto, 2001: 184).

Sistem perkawinan yang berlaku turun temurun di Selayar, umumnya bersifat monogami dan melarang terjadinya poligami. Pola pemilihan jodoh yang dipandang paling ideal, adalah memilih calon istri atau suami dalam lingkungan dan garis keturunan sendiri. Jodoh ideal yang dimaksudkan adalah pindu (sepupu dua kali) dan pinta' (sepupu tiga kali). Kentalnya kepercayaan mereka akan jodoh ideal tersebut, sehingga tidak jarang ada diantara anggota masyarakat yang menjodohkan anaknya sejak usia dini yang dalam bahasa setempat disebut lapassitanraang atau appassitanra. Meskipun demikian, hubungan keduanya belum berstatus 
tunangan (a'bajuang). Model pemilihan jodoh dalam perkawinan yang bersifat indogami tersebut, secara historis telah lama dipraktekkan. Meskipun demikian, tidak sedikit pula diantara anggota masyarakat yang memilih pasangan hidup di luar lingkungan keluarga (eksogami).

Pemilihan jodoh atau pasangan hidup di luar lingkungan keluarga (eksogami) bagi orangorang tertentu, bukan berarti menafikan konsep ideal tentang jodoh tadi yang biasanya dihubungkan dengan kepercayaan sipanaikang dalle (rezekinya cocok). Akan tetapi kecenderungan sebagian orang Selayar justru mencari atau menjodohkan anaknya di luar lingkungan keluarga (pantarang kampong) juga didasarkan atas pertimbangan sosio-kultural yakni dimaksudkan agar dapat memperluas hubungan keluarga (appakaluara bija). Istilah eksogami diidentikkan dengan pantarang kampong (di luar kampung), karena pada umumnya dalam sebuah kampung di Selayar berasal dari satu garis keturunan (assibija). Kalaupun ada yang berasal dari luar dapat dipastikan berasal dari keturunan bija silariang atau keluarga dari nenek atau kakek yang lain.

Kedua kecenderungan dalam sistem perkawinan ini, dalam tataran praktisnya tidak dapat diklaim bahwa pola pertama yakni indogami lebih ideal dibandingkan dengan model kedua yakni eksogami. Hal ini didasarkan atas kenyataan bahwa ukuran ideal dalam pandangan mereka bukan hanya berdasarkan kedekatan emosional dan kultural semata, akan tetapi juga didasarkan atas kecocokan menurut bintangnya (pendapat ahli nujum atau tau ngisse' = ramalan zodiak). Karena itu, setiap pasangan yang akan melangsungkan perkawinan terlebih dahulu ia diramal (ri bintang) oleh orang tertentu yang diangap memiliki otoritas tradisional dan tidak jarang dari mereka ada yang membatalkan perkawinan hanya karena dianggap tidak cocok (gelessituru bintangnya).

Berbagai alasan pembatalan tersebut biasanya karena pertimbangan gele sikalamberang (rumah tangga tidak langgeng) baik disebabkan oleh perpisahan (sisa'la tallasa) maupun salah satu dari pasangan itu meninggal dunia (sisa'la mate). Dasar pertimbangan pembatalan lainnya yakni gele situru dalle' (tidak cocok dari segi rezeki), yang jika ini tidak dihiraukan akan berdampak pada tidak adanya berkah dari usaha mereka. Meskipun ia berusaha semaksimal mungkin dalam menjalani hidup, tetap saja berada dalam kondisi yang sangat sederhana dari ukuran materi (kaasi-asi).

Fenomena menarik dari sistem kekerabatan lainnya dalam masyarakat Selayar, yakni sejak dahulu kala mereka memiliki prinsip kesetiaan yang dijunjung tinggi. Karena itu, dengan beberapa pengecualian semua pasangan yang telah melangsungkan akad nikah (memiliki ikatan perkawinan) sepakat untuk setia hingga akhir hayat dengan istilah pakkekepa passisa'la (hanya linggis yang dapat memisahkan). Makna istilah pakkeke dalam konteks ini, yakni linggis yang dipakai menggali liang lahat (lubang kuburan).

Prinsip kesetiaan yang dimiliki oleh masyarakat Selayar ini, pada dasarnya bukan sematamata karena pappasang to riolo (pesan/perintah atau anjuran leluhur) akan tetapi juga karena kedekatan emosional setiap pasangan. Kedekatan emosional yang dimaksudkan adalah karena umumnya mereka berasal dari keturunan yang sama (sibija) sehingga kemungkinan untuk berpisah sulit terjadi terutama jika dihubungkan dengan prinsip siritta ngaseng (harga diri bersama) yang dianut. Demikian kentalnya kepercayaan mereka terhadap konsep jodoh ideal tersebut, sehingga tidak jarang menjadi salah satu penyebab timbulnya kawin lari (silariang) terutama jika salah satu di kedua belah pihak keluarga tidak memberikan dukungan perjodohan (Ahmadin, 2004: 18). 
Berdasarkan kenyataan tersebut, bukan berarti bahwa orang Selayar steril dari keretakan rumah tangga (broken home) akan tetapi ada juga diantara mereka yang berpisah baik karena tidak cocok atau ada interest lain. Karena itu, di kalangan masyarakat Tana Doang ini sejak lama juga mengenal perbuatan selingkuh yang disebut sangkili (pasangan yang melakukan skandal ini disebut assangkili). Perbuatan asusila ini pun sering menjadi sebab perpisahan dan sudah barang tentu perbuatan ini sudah melanggar substansi karakter sosio-kultural yang telah menjadi bagian integratif dari masyarakat di pulau ini.

Ikatan kultural sesama orang Selayar di satu sisi, patut diakui sebagai salah satu wujud solidaritas mekanik yang mengedepankan prinsip integrasi. Hanya saja, pada sisi lainnya justru melahirkan kondisi ironis yang memalukan. Betapa tidak, berbagai prinsip yang dijadikan sebagai mekanisme integrasi rupanya akan berubah seiring dengan terjadinya rivalitas hidup. Kehidupan bersama di tanah rantau dengan perkembangan kondisi ekonomi rumah tangga yang variatif, tidak jarang memunculkan kecenderungan atau kebiasaan mendefinisikan kembali eksistensi mereka. Pada saat yang sama, jika para pendatang belakangan lebih dahulu berhasil maka akan menjadi sasaran kritikan bercampur iri. Beberapa contoh kasus menunjukkan bahwa efek dari rivalitas tidak sehat sesama orang Selayar di perantauan, menyebabkan ada yang terpaksa harus tersingkir secara sadis. Modus penyingkiran tersebut, dilakukan dengan menggunakan ilmu ghaib (semisal tenun, santet, doti) sehingga sanksi hukum tidak dapat menjerat pelaku.

Kejadian seperti ini lalu mengendorkan semangat dan motivasi untuk tampil dengan gaya hidup mewah, karena kemapaman dari segi ekonomi bukan garansi untuk hidup tenang. Sebaliknya, harta yang walaupun merupakan hasil jerih payah dan tetes keringat sendiri tidak jarang justru menjadi malapetaka bagi diri sendiri. Konsekuensi logis dari hal tersebut, melahirkan pesimisme sebagian orang dan menjadikan hidup sederhana sebagai pilihan terbaik.

Menganalisa secara elaboratif solidaritas mekanik orang Selayar berdasarkan ikatan kultural tersebut, dapat dipahami bahwa sifatnya tidak permanen. Sifat iri dan dengki pada orang lain (meskipun masih kerabat dekat) bawaan dari kampung halaman, menjadi kendala bagi pengembangannya secara kolektif. Dalam pengertian bahwa semakin besar jumlah anggota komunitas terutama di perantauan dan semakin maju tingkat pertumbuhan ekonomi, maka semakin tinggi pula tingkat konflik laten yang terjadi.

\section{Agama dan Kepercayaan}

Masyarakat Selayar mayoritas menganut ajaran Islam, meskipun ada diantaranya yang beragama lain yakni Kristen. Tidak diketahui mengenai kapan persis masuknya Islam, kecuali hanya bukti arkeologis. Bukti mengenai masuknya Islam di Selayar, adalah masjid tua yang terletak di Dusun Gantarang Desa Bontomarannu sekitar $12 \mathrm{~km}$ dari Kota Benteng. Menurut sejarahnya tempat ini pada abad ke-16 sangat penting sebagai tempat pertama masuknya Islam. Rumah ibadah ini sangat unik karena dibangun di atas sebuah sumur yang terletak di tengah kampung Gantarang dengan ditutup sebuah dulang emas. Fonomena unik lainnya yakni atap tumpang dan dilengkapi sebuah mustika pada puncaknya. Meskipun begitu, hingga kini penduduknya masih banyak yang percaya pada dunia ghaib, roh-roh halus, dan berbagai kekuatan sakti lainnya (religio-magis). Realitas ini mencerminkan bahwa sistem keberagamaan mereka bersifat sinkretis, yakni ajaran Islam yang bercampur kepercayaan asli (pra Islam). 
Kepercayaan akan dunia ghaib (dan mitologi) mengacu pada anggapan bahwa di balik dunia nyata, terdapat dunia lain yang tidak dapat dijangkau oleh kekuatan panca indera manusia. Dunia ghaib tersebut dalam pandangan mereka dihuni oleh makhluk-makhluk halus sakti dan hanya manusia yang mempunyai ilmu tertentulah yang sanggup menghadapi (atau mampu berkomunikasi). Makhluk halus seperti roh leluhur, jin, dewa, dan setan dapat saja mengganggu manusia jika mereka mau, karena itu penangkalnya (pa'rinring atau pa'bongka setan) harus dimiliki oleh setiap orang (Ahmadin, 2004: 5).

Makhluk halus tersebut menurut anggapan mereka, pada umumnya menghuni pohon-pohon besar, batu besar, gunung, sungai, gua-gua, dan laut yang disebut pakkammik. Karena itu, tidak heran jika di kalangan masyarakat sering terdengar orang menyebut setang tamparang, setang kaju, setang je'ne (sungai) dan jenis setan lainnya (Ahmadin 2003: 3). Dalam bahasa Makassar, para penghuni tempat-tempat keramat itu juga dinamakan pakkammik (penjaga, penguasa), yang menguasai tempat tertentu. (Hamid, 1994/1995: 27).

Meskipun penduduk kabupaten Selayar mayoritas menganut ajaran agama Islam, namun dalam pelaksanaan syari'at sebagian besar masih diwarnai oleh sisa-sisa pengaruh ajaran agama Hindu. Hal ini tentu disadari bersama bahwa secara historis, agama inilah yang sesungguhnya lebih awal masuk dan berpengaruh di Indonesia yakni sejak abad ke-5 atau abad ke-7 M (Soekmono, 1995: 7) dibandingkan agama Islam baru pada abad ke-7 dan $8 \mathrm{M}$ dan menjadi agama kerajaan sekitar abad ke-13 M (Hasymy, Ed, 1989: 420).

Ajaran Hindu yang lebih awal berpengaruh di Indonesia, rupanya telah menyimpan sisa-sisa kepercayaan yang masih dipegang teguh oleh sebagian besar masyarakat Selayar. Realitas tersebut tercermin melalui kebiasaan membakar kemenyan (dupa), menyiapkan sesajen, bungabungaan terutama dalam pelaksanaan upacara keagamaan dan upacara daur hidup. Upacara tersebut terdiri atas upacara memulai penebangan hutan (membuka lahan baru), memulai penanaman padi, panen, membuat emping/hasil laut, menghindarkan diri dari wabah penyakit (songkabala), upacara meminta hujan dan lain-lain (Sukirman 1994/1995).

Lain lagi dengan mereka yang akan pindah rumah atau menempati rumah baru (nai' balla atau lette balla) umumnya diadakan acara assuro masa (menyuruh dukun/guru membaca mantra). Kegiatan masa (mungkin asal katanya ambasa = membaca), dilengkapi dengan kemenyan atau dupa, buah pisang, tebu, beras ketam hitam/putih, telur, susuru (cucuru, Makassar), dan kelengkapan ritual lainnya. Setelah kegiatan assuro masa ini selesai, semua songkolo (beras ketam yang dimasak) yang tadinya diletakkan di setiap tiang rumah (benteng) serta di depan sang guru (di tiang tengah) kemudian dimakan secara bersama-sama (a'limbo nganre = makan bersama).

Khusus masyarakat yang mendiami wilayah pesisir pantai serta sebagian yang sering ke laut, sejak zaman dahulu nenek moyang mereka percaya pada penghuni laut yakni Nabi Heddere' (Nabi Khaidir). Namun demikian, sejak tahun 1970-an hingga sekarang tampaknya kepercayaan tersebut lambat laun mulai hilang. Selain agama Islam yang dianut dengan baik, pengaruh perkembangan teknologi pun merupakan faktor penyebab perubahan kepercayaan tersebut. Selain kepercayaan baik menyangkut ritual maupun normatiftersebut, di kalangan masyarakat Selayar juga mengenal dan percaya pada kekuatan nasib (sareng) yang sangat berpengaruh secara signifikan terhadap kehidupan manusia. Demikian kentalnya kepercayaan pada kekuatan nasib ini sehingga sering dijadikan dijadikan sebagai tujuan akhir dari sebuah usaha (puncak perjuangan). 
Dalam hubungannya prinsip hidup, orang Selayar juga percaya pada pertolongan yang maha kuasa terhadap hamba-Nya yang berada dalam kesulitan. Karena itu mereka percaya bahwa pada kondisi kritis/genting, akan datang pertolongan melalui ilmu kesaktian (pangissengan) baik karena berkah mantar ataupun disebabkan karena sebuah kekuatan telah menjadi bagian dari dirinya. Kondisi genting seperti ini dalam bahasa setempat dinamakan si-hali tondo' si-hali katinting (satu bagian yang harus dilalui adalah pagar dan bagian lain adalah duri). Dalam pengertian lain bahwa keadaan ini menyebabkan seseorang berada dalam kondisi ketiadaan pilihan lain atau keadaan genting (tide' pamuleleang), sehingga solusi paling tepat adalah sikap pasrah.

Timbulnya kecenderungan untuk tetap mempertahankan nilai-nilai budaya (tradisi) tersebut hingga eksis sampai sekarang, pada prinsipnya disebabkan oleh pengaruh lingkungan. Hal ini dipahami mengingat bahwa hubungan manusia dengan alam termasuk dalam salah satu dari 5 masalah pokok yang dihadapi manusia secara universal yakni persoalan mengenai sifat dasar manusia (human nature), hubungan manusia dengan alam, titik masa yang menjadi perhatian kehidupan manusia, kegiatan manusia, dan hubungan antar manusia dengan sesamanya (Kluckhohn dan Stodbeck., 1961; Marzali., 2002: 18).

\section{Kesimpulan}

Berdasarkan uraian mengenai warisan budaya orang Selayar tersebut, maka dapat dikemukakan beberapa kesimpulan sebagai berikut :

Pertama, stratifikasi sosial yang berlaku pada masyarakat Selayar juga menerapkan tingkatan sebagaimana lazimnya semua masyarakat. Dalam pengertian bahwa golongan sosialnya juga terdiri dari golongan atas (upper class) yang dinamakan anak karaeng (keluarga opu), menengah (midle class) yang disebut tau samara, dan bawah (lower class) yang diistilahkan ata. Meskipun demikian, belakangan ini strtatifikasi sosial tersebut tampaknya nyaris tidak ada lagi sebaliknya indikator ekonomi yang justru menentukan status sosial.

Kedua, sistem kekerabatan terbentuk melalui dua pola, yakni pola kelahiran dan perkawinan. Terminologi kerabat dalam bahasa Selayar disebut bija, yang dapat digolongkan menjadi dua bagian yakni bija pammanakang dan bija passianakang. Kategori bija pertama adalah kelompok kekerabatan yang terbentuk melalui jalur kelahiran dan kategori bija kedua terbentuk melalui jalur ikatan perkawinan. Sementera itu, kekerabatan dalam unit sosial terkecil dinamakan bija pammanakang sibatu sapo, yakni mencakup keluarga luar (extended family) dan segenap keluarga yang tinggal bersama-sama dalam satu rumah tangga atau nuclear family.

Ketiga, umunya masyarakat Selayar menganut agama Islam meskipun bercampur dengan kepercayaan akan dunia ghaib (dan mitologi) mengacu pada anggapan bahwa di balik dunia nyata, terdapat dunia lain yang tidak dapat dijangkau oleh kekuatan panca indera manusia. Dunia ghaib tersebut dalam pandangan mereka dihuni oleh makhluk-makhluk halus sakti dan hanya manusia yang mempunyai ilmu tertentulah yang sanggup menghadapi (atau mampu berkomunikasi). Makhluk halus seperti roh leluhur, jin, dewa, dan setan dapat saja mengganggu manusia jika mereka mau, karena itu penangkalnya (pa'rinring atau pa'bongka setan) harus dimiliki oleh setiap orang. 


\section{KEPUSTAKAAN}

Ahmadin. 2001. Modernisasi Dalam Bidang Penangkapan Ikan : Studi Sejarah Sosial Komunitas Nelayan di Kampung Padang Kab. Selayar. Makassar: Tesis PPs UNM.

---------. 2002. Ulukalo : Satu Sisi Kehidupan Orang Selayar di Perantauan. Makassar : Makalah Unpublihied.

--------. 2003. Orang Selayar : Bergumul diantara Dominasi Relegio-magis. MakalahUnpublished.

---------. 2004. Menangkap Makna Ragam Kearifan Lokal di Tanah Bugis-Makassar. MakalahUnpublished.

---------. 2004. Pemikiran Orang Selayar dalam Bingkai Mitologi. Makassar : MakalahUnpublished.

Durkheim, Emile. 1984. Devision of Labor in Society. New York : The Free Press A Devision of Macmillan, Inc.

Erington, Shelly. 1979. Meaning and Power in Southeast Asian Realn. New Jersei : Princeten University Press.

Hamid, Abu. 1994/1995. Suatu Tinjauan Sosio Antropologi Ekonomi Tentang Peningkatan Kesejahteraan Kehidupan Nelayan dan Sektor Kemaritiman di Sulawesi Selatan. Ujung Pandang: Le mbaga Penelitian UNHAS).

Hasymy, A. Ed. 1989. Sejarah Masuk dan Berkembangnya Islam di Indonesia.. Bandung: Almaarif.

Iver, Robert M. Mac dan Charles H. Page. 1957. Society : An Introductory Analysis.. New York : Rinehart and Company, Inc.

Kluckhohn dan Stodbeck. 1961. Variation in Value Orientation. Evanston, Illinois: Row, Peterson \& Co.

Marzali, Amri. 2002. "Pergeseran Orientasi Nilai Kultural dan Keagamaan di Indonesia: Sebuah Esei dalam Rangka Mengenang Almarhum Prof. Koentjaraningrat" dalam Antropologi Indonesia, S7 (XXII).

Mattulada. 1975. Latoa : Suatu Lukisan Analisis Terhadap Antropologi Politik Orang Bugis. Jakarta: Disertasi Universitas Indonesia.

Robinson, Kathryn dan Mukhlis, ed., 1985. Masyarakat Pantai.. Ujung Pandang : Lembaga Penelitian Universitas Hasanuddin.

Soekanto, Soerjono. 2001. Sosiologi Suatu Pengantar. Jakarta: Raja Grafindo Persada.

Soekmono. 1995. Pengantar Sejarah Kebudayaan. Yogyakarta: Kanisius.

Sukirman. 1994/1995. Laporan Penelitian Sejarah dan Nilai Tradisional Sulawesi Selatan.. Ujung Pandang: Departemen Pendidikan dan Kebudayaan Direktorat Jenderal Kebudayaan Balai Kajian Sejarah dan Nilai Tradisional.

Tylor, Edward B. 1924. Primitive Culture : Researches into the Development of Mythology, Philosophy, Religion, Language, Art and Costom. Boston : Estes \& Lauriat. 